\title{
Hubungan Imunoekspresi Annexin V (ANX V) dengan Histopatologi Jaringan Kuretase pada Abortus Berulang
}

\author{
Fairuz $^{1}$, Hasna Dewi ${ }^{1}$, Suhair ${ }^{2}$ \\ ${ }^{1}$ Departemen Patologi Anatomi, Fakultas Kedokteran dan Imu Kesehatan, Universitas Jambi \\ ${ }^{2}$ Bagian Obstetri dan Ginekologi, RS Abdul Manap, Kotamadya Jambi \\ Email: fairuzquzwain@gmail.com
}

\begin{abstract}
Background : Abortion the ending of pregnancy due to removing an embryo or fetus before it can survive outside the uterus. Examination on placental tissue currently does not provide much information. Annexin V (ANX V), formerly known as placenta anticoagulant protein and alpha coagulant vascular, is found in the placenta and vascular endothelium and several other tissues. This ANX V is found at the top of the placenta syncytiotrophoblast, and it is also found that this protein content freely decreases with the antiphospholipid syndrome (APS). This study aimed to assess the relationship between the description of ANX V expression and histopathology of curettage tissue in patients with recurrent abortion.

Methods : This study was conducted using curettage tissue samples of patients with recurrent abortion in the Obstetrics and Gynecology section of Abdul Manap Hospital and Baiturahim Hospital in February to August 2018. The collected samples were diagnosed with HE preparations, to determine histopathological features in each group, villi infarction. hydrophic villi, sincytial knots, fibrin stroma and inter villi thrombus with the highest total score were 15. Then immunohistochemical assessment with Annexin $V(A N X V)$ results compared with positive controls and negative controls with cut-off points $10 \%$.

Results: We have found a recurrent abortion sample with positive Annexin $V$ immunoexpression, which is the most common histopathological score of $11-15$ on recurrent abortion $(p=0.001$ and $r=-0.784)$

Conclusion: There is a relationship between immunohistochemistry ANX $V$ with histopathological features of recurrent abortion curettage.
\end{abstract}

Keywords: Annexin V, Histopathology, Recurrent abortion

\section{ABSTRAK}

Latar Belakang: Abortus adalah keadaan pengeluaran hasil konsepsi sebelum janin dapat hidup di luar kandungan. Pemeriksaan pada jaringan plasenta saat ini tidak banyak memberikan informasi. Annexin $V$ (ANX V), dulu dikenal dengan placental anticoagulant protein I dan vascular coagulant alfa, ditemukan di plasenta dan endotel vaskular dan beberapa jaringan yang lain. ANX $\mathrm{V}$ ini ditemukan di puncak permukaan sinsitiotrofoblas plasenta, dan ditemukan pula bahwa kadar protein ini secara bermakna menurun di villi plasenta penderita abortus dengan antiphospholipid syndrome (APS). Penelitian ini bertujuan melihat hubungan gambaran ekspresi ANX $\vee$ dengan histopatologi jaringan kuretase pada penderita abortus berulang.

Metode : Penelitian ini dilakukan dengan menggunakan sampel jaringan kuretase pasien abortus berulang di bagian Obstetri dan Ginekologi RS Abdul manap dan RS Baiturahim periode februari sampai agustus 2018. Sampel yang terkumpul dilakukan diagnosis terhadap sediaan HE, untuk menetukan gambaran histopatologis pada masing-masing kelompok yaitu infark villi, hidrofik villi, sincytial knots, fibrin stroma serta trombus inter villi dengan skor total tertinggi adalah 15 . Kemudian dilakukan 
pemulasan dan penilaian imunohistokimia dengan Annexin V (ANX V) Hasil pulasan imunohistokimia Anti ANX V dibandingkan dengan kontrol positif dan kontrol negative dengan cut-off point $10 \%$.

Hasil: Didapatkan 30 sampel abortus berulang dengan imunoekspresi Annexin $\vee$ positif, didapatkan paling banyak dengan skor histopatologi 11- 15 pada abortus berulang ( $p=0.001$ and $r=-0.784$ ).

Kesimpulan: Terdapat hubungan antara imunohistokimia ANX V dengan gambaran histopatologi pada kuretase abortus berulang.

Kata Kunci: Annexin V, Histopatologi, Abortus berulang

\section{PENDAHULUAN}

Abortus adalah suatu istilah yang digunakan untuk menunjukkan keadaan pengeluaran hasil konsepsi sebelum janin dapat hidup di luar kandungan, yaitu sebelum janin mencapai berat 500 gram atau umur kehamilan kurang dari 20 minggu. Hal ini didasari fakta bahwa janin yang dilahirkan dengan berat badan di bawah 500 gram sangat jarang yang dapat hidup di luar kandungan. Berdasarkan mekanisme terjadinya, istilah abortus dibedakan menjadi abortus spontan dan abortus buatan. Abortus yang berlangsung tanpa tindakan disebut abortus spontan. ${ }^{1,2}$ Prevalensi abortus juga meningkat dengan bertambahnya usia, di mana pada wanita berusia 20 tahun adalah $12 \%$, dan pada wanita di atas 45 tahun adalah $50 \%$. Delapan puluh persen abortus terjadi pada 12 minggu pertama kehamilan. Penelitian- penelitian terdahulu menyebutkan bahwa angka kejadian abortus sangat tinggi. ${ }^{3}$ Sebuah penelitian tentang hubungan antara antibodi antifosfolipid dan abortus berulang di Indonesia dilakukan oleh Kusworini dkk, pada tahun 1993. Hasil penelitian tersebut menunjukkan adanya prevalensi ACA dan LA yang nyata lebih tinggi pada penderita abortus berulang dibandingkan dengan pada tahun 1993 memperkirakan total kejadian abortus di Indonesia berkisar antara 750.000 dan dapat mencapai 1 juta per tahun dengan rasio 18 abortus per 100 konsepsi. Angka tersebut mencakup abortus spontan maupun buatan. Mekanisme pasti yang bertanggungjawab atas kejadian abortus tidak selalu tampak jelas. Terdapat banyak penyebab terjadinya abortus, salah satunya adalah faktor imunologi. Kelainan imunologi dapat menyebabkan terjadinya gangguan koagulasi yang dapat menyebabkan trombosis pada arteri spriralis. Faktor imunologi telah terbukti signifikan dapat menyebabkan abortus spontan yang berulang antara lain disebabkan adanya antibodi antifosfolipid pada antiphospholipid syndrome (APS) . Antibodi antifosfolipid yang terpenting dalam klinis yaitu lupus anticoagulant (LA) dan anticardiolipin antibody (ACA) yang mengakibatkan destruksi vaskuler, trombosis, abortus serta destruksi plasenta. ${ }^{4,5}$

Laporan penelitian pertama kali orang sehat (berturut-turut 18\% : 3,8\% dan $4 \%: 0 \%$, p. 0,05$).{ }^{6}$ Pada APS terjadi trombosis vaskularisasi plasenta, sehingga menyebabkan abortus berulang. Kejadian yang sering dilaporkan di kelompok wanita usia subur adalah abortus berulang oleh karena adanya infark yang luas di plasenta. 
Adanya trombosis dan vaskulopati arteri spiralis ibu menyebabkan isufisiensi dan hipoksia jaringan plasenta. Hal ini yang dapat menyebabkan abortus. Teori yang sederhana sebagai penyebab abortus pada APS adalah darah kental tidak mampu melewati pembuluh darah paling kecil di plasenta. Plasenta mengkerut dan embrio/fetus tidak dapat hidup dan terjadilah keguguran. ${ }^{2,7}$

Pemeriksaan pada jaringan plasenta saat ini tidak banyak memberikan informasi. Saat ini pemeriksaan jaringan kuretase hanya diperlukan dalam penetapan jaringan yang diambil merupakan suatu jaringan kehamilan atau untuk mendapatkan informasi adanya kelainan trofoblas seperti mola hidatidosa. Tidak ada suatu protokol pemeriksaan pada jaringan plasenta yang dapat diperoleh dari jaringan kuretase. Banyak laporan penelitian yang menggambarkan histopatologi jaringan plasenta, salah satunya adalah gambaran trombosis dan vaskularisasi.VanHorn (2004) melakukan penelitian gambaran histopatologi jaringan kuretase dan menyimpulkan gambaran yang hampir sama pada penderita APS ataupun antiphospholipid-like syndrome (APS-like), tetapi tidak membandingkan dengan gambaran histopatologi jaringan kuretase pada penderita bukan APS. Perbedaan gambaran histopatologi yang sulit ini membuat diperlukannya suatu petanda/marker lain yang diharapkan dapat membantu dalam penegakan diagnosis APS pada penderita abortus berulang. ACA merupakan suatu antibodi yang bekerja melawan kardiolipin dan ditemukan pada beberapa penyakit seperti sifilis, APS, vaskulitis, termasuk juga idiopathic spontaneous abortion. Antibodi ini dibentuk oleh anti-mitochondrial antibody. Pada penyakit-penyakit autoimun, antibodi ini berikatan dengan Beta 2 glycoprotein-1 (B2GP-1) yang menyebabkan suatu trombosis. $^{8,9,10}$

Annexin V (ANX V), dulu dikenal dengan placental anticoagulant protein I dan vascular coagulant alfa, ditemukan di plasenta dan endotel vaskular dan beberapa jaringan yang lain. Protein ini yang fungsi biologisnya belum diketahui, mempunyai kemampuan antiokoagulan yang didasarkan atas afinitasnya yang tinggi terhadap anionic phospholipid. Dilaporkan bahwa ANX V ini ditemukan di puncak permukaan sinsitiotrofoblas plasenta, dan ditemukan pula bahwa kadar protein ini secara bermakna menurun di villi plasenta penderita APS. Antibodi anti ANX V (anti ANX V) diduga mempunyai peranan dalam menurunkan kemampuan ANX $\mathrm{V}$ untuk berikatan dengan membran trofoblas dan menyebabkan trombosis plasenta nekrosis dan akhirnya kematian janin. 6,11,12

Pada penelitian ini menuilai ekspresi anti ANX V pada sampel jaringan plasenta merupakan jaringan kuretase pada penderita abortus berulang,

\section{METODE PENELITIAN}

Sampel penelitian penderita abortus berulang di Kota Jambi yang memenuhi kriteria klinis aPL positif dan aPL negatif, aPL positif yaitu : 1.Penderita yang mengalami abortus berulang sama atau 
lebih dari 2 kali 2.Umur kehamilan sama atau kurang dari 12 minggu 3. Terdapat riwayat preeklampsi atau ekplampsi sebelumnya. 4. Terdapat riwayat IUFD diatas 6 minggu. Sampel yang terkumpul dilakukan diagnosis terhadap sediaan HE, untuk menetukan gambaran histopatologis pada masing-masing kelompok yaitu infark villi (1-3), hidrofik villi (1-3), sincytial knots (1-3), fibrin stroma (1-3) serta trombus inter villi (1-3). Total skor dijumlahkan kemudian dibagi menjadi 3 kelompok yaitu 1 sampai 5, 6 sampai 10, dan 11 sampai 15. Kemudian dilakukan pemulasan dan penilaian imunohistokimia dengan Annexin V (ANX V), Hasil pulasan imunohistokimia Anti ANX V dibandingkan dengan kontrol positif dan kontrol negatif. Penghitungan sel yang imunoreaktif dilakukan di bawah mikroskop cahaya pada 5 LPB yaitu dengan pembesaran 400x. Penilaian imunoekspresi Ati ANX V dinyatakan dalam rendah dan tinggi, dengan cut-off point $10 \%$. Rendah bila membran sel terpulas < $10 \%$ dan tinggi bila membran terpulas > $10 \%$.

\section{HASIL PENELITIAN}

Didapatkan 30 sampel sampel jaringan kuretase abortus berulang. Pada tabel 1 menjelaskan karakteristik secara. Secara histopatologis, tidak didapatkan perbedaan gambaran infark villi, syntitial knot maupun hidrofik villi pada kedua kelompok. Gambar 1A menunjukkan imunoekspresi Annexin $\mathrm{V}>10 \%$ dan $1 \mathrm{~B}$ menunjukkan imunoekspresi Annexin $\mathrm{V}<10$.
Perbedaan yang signfikan ditemukan pada gambaran trombus intrvilli maupun fibrin pada stroma (gambar 1). Pada tabel 1 juga menjelaskan secara rinci distribusi gambaran histopatologi. Tampak bahwa adanya peningkatan skor histopatologi ditandai dengan peningkatan trombus intervilli dan adanya fibrin pada stroma serta kelompokan syntitial knot.

Tabel 1. Karakteristik Subjek Penelitian dan skor histopatologi berdasarkan imunoeksptersi ANX V

\begin{tabular}{lc}
\hline \multicolumn{1}{c}{ Variabel } & $\mathbf{N}=\mathbf{3 0}$ \\
\hline Usia (tahun) & \\
Rata-rata \pm Std & $35,11 \pm 6,06$ \\
Median & 37,50 \\
Rentang (min-maks) & $31,00-42,00$ \\
Paritas & \\
$2-3$ & $22(73,3 \%)$ \\
$3-4$ & $6(20,0 \%)$ \\
$>4$ & $2(6,7 \%)$ \\
Riwayat & \\
Pre eklampsi/eklampsi & $12(40,0 \%)$ \\
IUFD & $2(6,7 \%)$ \\
Tidak ada kelainan & $16(53,3 \%)$ \\
\hline
\end{tabular}

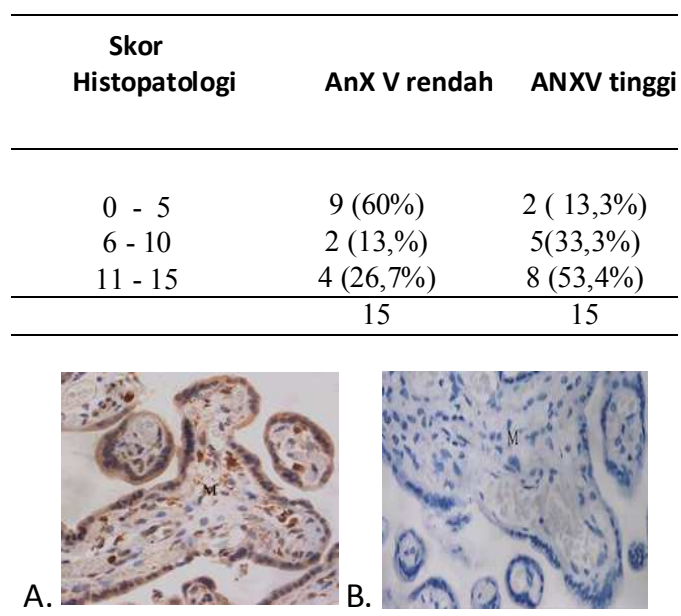

Gambar 1. A. Imunoekspresi ANXV >10\% B. Imunoekspresi ANXV $<10 \%$

\section{DISKUSI}

Istilah abortus dipakai untuk menunjukkan pengeluaran hasil kehamilan sebelum janin 
dapat hidup di luar kandungan. Sampai saat ini janin yang terkecil, yang dilaporkan dapat hidup di luar kandungan, mempunyai berat badan 297 gram waktu lahir. Akan tetapi karena jarangnya janin yang dilahirkan dengan berat badan di bawah

500 gram dapat hidup terus, maka abortus dianggap sebagai pengakhiran kehamilan sebelum janin mencapai berat 500 gram atau usia kehamilan kurang dari 20 minggu. Abortus dapat berlangsung spontan secara alamiah atau buatan. Abortus buatan ialah pengakhiran kehamilan sebelum 20 minggu dengan obat-obatan atau dengan tindakan medik. Berdasarkan aspek klinisnya, abortus spontan dibagi menjadi beberapa kelompok, yaitu abortus iminens (threatened abortion), abortus insipiens (inevitable abortion), abortus inkomplit, abortus komplit, missed abortion, abortus habitualis (recurrent abortion), abortus servikalis, abortus infeksiosus, dan abortus septik. ${ }^{1,2}$ Seorang wanita dikatakan menderita abortus habitualis apabila ia mengalami abortus berturut-turut 3 kali atau lebih. Wanita tersebut umumnya tidak sulit hamil, akan tetapi kehamilannya tidak dapat bertahan terus sehingga wanita yang bersangkutan tidak dapat melahirkan anak yang hidup. Keadaan tersebut dapat digolongkan sebagai infertilitas atau sterilitas. Terdapat banyak kemungkinan penyebab dasar abortus habitualis, kurang lebih $40 \%$ sebab dasarnya tidak diketahui. Penyebab abortus berulang yang diketahui yakni: Kelainan genetik (kromosomal) pada suami atau istri, gangguan nutrisi, penyakit infeksi, kelainan koagulasi dan pembuluh darah atau kelainan pada serviks dan uterus. ${ }^{6}$

Adanya gangguan perdarahan uteroplasenta diketahui merupakan salah satu penyebab terjadinya abortus berulang. Antiphospholipid Syndrome (APS) adalah gangguan outoimun yang ditandai oleh trombosis pembuluh darah vena dan atau arteri, abortus berulang yang berhubungan dengan trombosis di vaskularisasi plasenta, trombositopeni, antibodi antifosfolipid di dalam darah. APS sekarang mulai dikenal sebagai salah satu penyebab kasus abortus habitualis. Antibodi antifosfolipid adalah autoantibodi terhadap antigen yang terdiri dari fosfolipid bermuatan negatif. Bagaimana timbulnya antigen tersebut belum diketahui. Antibodi antifosfolipid terdiri dari IgG, IgM dan IgA.

Tiga mekanisme potensial antibodi antifosfolipid dalam menginduksi trombosis yakni:

1. Sel endotel secara normal mengubah asam arakidonat membran plasma menjadi prostasiklin.

2. Trombosit secara normal merubah asam arakidonat membran plasma menjadi tromboksan.

3.Kompleks trombin dan trombomodulin secara enzimatik bersifat aktif dan dapat mengaktifkanprotein $\mathrm{C}$ dalam sirkulasi.

Annexin V (ANX V) dulu dikenal dengan placental anticoagulant protein I dan vascular coagulant alfa, ditemukan di plasenta dan endotel vaskular dan beberapa jaringan yang lain. $A N X V$ merupakan bagian dari kelompok ubiquotus, non glycocylated protein yang 
menempel pada fosfolipid. Protein ini yang fungsi biologisnya belum diketahui, mempunyai kemampuan antiokoagulan yang didasarkan atas afinitasnya yang tinggi terhadap fosfolipid anion. Gen ANX V terletak pada kromosom 4q26-q28, yang menghasilkan ANX $\mathrm{V}$ yang terdiri dari 320 residu asam amino. ANX V berikatan dengan fosfolipid permukaan membran yang bermuatan negatif, sehingga mencegah terikatnya faktor-faktor pembekuan darah yang tergantung fosfolipid anion, dan menghambat aktivasi protrombin. Dilaporkan bahwa ANX V ini ditemukan di puncak permukaan sinsitiotrofoblas plasenta dan sel endotel. Adanya penurunan kadar ANX $\mathrm{V}$ diduga berperan dalam pembentukan trombus pada abortus habitualis pada kelainan APS . Menurut Rand, dkk, B2GP-1 yang berikatan dengan membran anionik pada domain $V$ diduga menghambat menempelnya ANX $V$ pada membran fosfolipid sehingga menurunkan kemampuannya dalam menghambat terjadinya koagulasi. ${ }^{13,14,15}$

Gejala klinis APS sangat bervariasi mulai dari sub akut seperti migrain berulang, gangguan penglihatan, disarthria, trombosis vena dalam, keguguran berulang, sampai yang berat seperti gagal katup jantung yang akut, trombositopenia, stroke mayor dan trombosis tersebar luas. Semua pembuluh darah dapat terkena mulai dari aorta, arteri karotis, arteri pulmonalis dan arteri kecil. Akibatnya semua bagian tubuh bisa terkena, termasuk retina dan kulit. Antibodi dapat persisten beberapa tahun dan barang kali di sejumlah kecil penderita dapat menetap seumur hidup. Diagnosis pasti APS memerlukan minimal satu kriteria klinis dan satu kriteria laboratoris. Pada APS terjadi trombosis vaskularisasi plasenta,sehingga menyebabkan abortus berulang. Kejadian yang sering dilaporkan di kelompok wanita usia subur adalah abortus berulang oleh karena adanya infark yang luas di plasenta. Adanya trombosis dan vaskulopati arteri spiralis ibu menyebabkan insufisiensi dan hipoksia jaringan plasenta. Hal ini yang dapat menyebabkan abortus. Teori yang sederhana sebagai penyebab abortus di APS adalah darah kental tidak mampu melewati pembuluh darah paling kecil di plasenta. Plasenta mengkerut dan embrio/fetus tidak dapat hidup dan terjadilah keguguran. $^{2}$

Banyak dilaporkan adanya perubahan plasenta pada penderita APS, walaupun masih mempunyai gambaran yang bervariasi. Menurut VanHorn (2004) lebih banyak didapatkan adanya infark villi, intervillous fibrin, vessel thrombosis, intervillous thrombus, syncytial knot, decidual necrosis, dan decidual vessel thrombus, walaupun gambaran ini dapat juga ditemukan pada penderita abortus dengan antiphospholipid-like syndrome dan Stone (2006) menemukan adanya banyak sel-sel radang terutama makrofag pada plasenta juga ditemukan pada APS. Pada beberapa kasus ditemukan pula kalsifikasi plasenta yang terbentuk karena deposit fibrin pada permukaan trofoblas villi dan tertutupnya lumen pembuluh darah sebagian atau seluruhnya oleh trombosis. $^{6,17,18}$ 


\section{DAFTAR PUSTAKA}

1. Cunningham, FG., Leveno, Bloom, SL, Spong, CY, Dashe,.., Abortion. In: Williams Obstetrics. 24th, United States, McGraw-Hill Education, 2014, 350-71,1173-76.

2. Branch DW, Gibson M, Silver RM. Recurrent miscarriage. N Engl J Med. 2010;363:18

3. Erkan D, Kozora E, Lockshin MD: Cognitive dysfunction and white matter abnormalities in antiphospholipid syndrome. Pathophysiology 18(1):93, 2011

4. Garg, N, Deodhar, A. The Sydney Classification Criteria for Definite Antiphospholipid Syndrome. J Musculoskel Med. 2012;29:73-77

5. Alsibiani S., 2014. Value of histopathological examination of uterine products after first-trimester niscarriage. Biomed Research Int. 2014:1

6. Kalalo LP., Darmadi S., Dachlan EG., Abortus habitualis pada antiphospholipid syndrome. Indonesian Journal of Clinical Pathology and Medical Laboratory. 2006;12(2):82-7

7. Giannakopoulos B, Krilis SA: The pathogenesis of the antiphospholipid syndrome. N Engl J Med 368(11):1033, 2013

8. Jindal P., et al. Placental pathology of recurrent spontaneous abortion: the role of histopathological examination of products of conception in routine clinical practice: a mini review. Human Reproduction. 2007; 22(2): 313-6

9. VanHorn JT., Craven C., Ward K., Branch W, Silver RM. Histologic features of placentas and abortion specimen from women with antiphospholipid and antiphospholipid-like syndrome. Placenta. 2004; 26: 642-8

10. Vahist A., Regan L., Antiphospholipid syndrome- An update. R Coll Physicians Edinb 2005; 35:337-339

11. Hanly JG., Smith SA., Anti-b2-glycoprotein I (GPI) autoantibodies, annexin V binding and the anti-phospholipid syndrome. Clin Exp Immunol 2000; 120:537-543

12. Simone ND., Castellani R., Caliandro D., Caruso A. Monoclonal Anti-Annexin V Antibody Inhibits Trophoblast Gonadotropin Secretion and Induces Syncytiotrophoblast Apoptosis. Biology of reproduction. 2001; 65,:176670

13. Rand JH., et al.. Antiphospholipid Antibodies Accelerate Plasma Coagulation by Inhibiting Annexin-V Binding to Phospholipids: A “Lupus Procoagulant” Phenomenon. J of American society of hematology . 1998;92(5):165260

14. Gharib MN., Elhawary TM., Elshourbagy SH., Morad MA. Anti-annexin V antibodies in women with reccurent miscarriage. Clinical Medicine Insight:Reproductive Health. 2010;4:29-33

15. Hanly JG., Smith SA., Anti-b2-glycoprotein I (GPI) autoantibodies, annexin V binding and the anti-phospholipid syndrome. Clin Exp Immunol 2000; 120:537-543

16. Stone S., et al. The placental bed in pregnancies complicated by primary antiphospholipid syndrome. Placenta. 2006;27(4):457-67

17. Tripodi A., Groot PG., Pengo V., Antiphospholipid syndrom: laboratory detection, mechanisms of action and treatment. J Int medicine. 2011;10:1-13

18. Sebire NJ., et al. Placental pathology, antiphospholipid sntibodies, and pregnancy outcome in reccurent miscarriage patients. Obstet Gynecol. 2003;101:258-63 